\title{
HUBUNGAN STATUS GIZI DAN STATUS IMUNISASI DENGAN KEJADIAN INFEKSI SALURAN PERNAFASAN AKUT PADA BALITA KOTA PADANG
}

\author{
Dwi Christina Rahayuningrum ${ }^{1}$, Siti Aisyah Nur $^{2}$ \\ ${ }^{1,2}$ Sekolah Tinggi IImu Kesehatan Syedza Saintika Padang \\ Email : noeninksweet@gmail.com
}

\begin{abstract}
The proportion of under-five morbidity due to ARI is still the biggest cause of death among children under five. Many factors influence the high incidence of ARI, including nutritional status and immunization status. Toddlers with poor nutrition will be more susceptible to infection with ARI than children with normal nutritional status, under five who do not get complete immunization will be at risk of developing ARI. The purpose of this study was to determine the relationship between nutritional status and immunization status with the incidence of $A R I$ in toddlers. This research uses quantitative analytic method with cross sectional approach. The population in this study were all mothers who had children aged 1-5 years who visited the Lubuk Buaya Health Center as many as 627 under-five. The sampling technique was accidental sampling with a sample size of 86 toddlers. Data collection was carried out using observation sheets. The results obtained $58.1 \%$ of respondents with the incidence of $A R I, 47.7 \%$ of respondents with low nutritional status, $64 \%$ of respondents with incomplete immunization status. It is concluded that there is a relationship between nutritional status and immunization status with the incidence of $A R I$, it is hoped that mothers of toddlers can increase nutritional intake for under-nutrition children and it is hoped that health center officers will provide information to mothers about the importance of immunization.
\end{abstract}

\section{Keyword : Incidence of ARI, Nutritional Status, Immunization Status, Toddler}

Abstrak : Proporsi kesakitan Balita akibat ISPA masih merupakan penyebab kematian terbanyak pada Balita. Banyak faktor yang mempengaruhi tingginya kejadian ISPA diantaranya yaitu status gizi dan status imunisasi. Balita dengan keadaan gizi yang kurang akan lebih mudah terserang ISPA dibandingkan Balita dengan status gizi normal, Balita yang tidak mendapatkan imunisasi lengkap akan beresiko terserang ISPA. Tujuan penelitian ini untuk mengetahui hubungan antara status gizi dan status imunisasi dengan kejadian ISPA pada Balita. Penelitian ini menggunakan metode analitik kuantitatif pendekatan cross sectional. Populasi dalam penelitian ini adalah semua ibu yang mempunyai anak Balita usia1-5 tahun yang berkunjung ke Puskesmas Lubuk Buaya sebanyak 627 Balita,tehnik pengambilan sampel dengan cara accidental sampling dengan jumlah sampel 86 Balita. Pengumpulan data dilakukan dengan menggunakan lembar observasi. Hasil penelitian didapatkan $58,1 \%$ responden dengan kejadian ISPA $47,7 \%$ responden dengan status gizi kurang $64 \%$ responden dengan status imunisasi tidak lengkap. Disimpulkan ada hubungan status gizi dan status imunisasi dengan kejadian ISPA, maka diharapkan kepada ibu Balita agar dapat meningkatkan asupan nutrisi pada Balita yang gizi kurang dan diharapkan kepada petugas Puskesmas agar memberikan penyuluhan kepada ibu tentang pentingnya imunisasi.

Kata kunci : Kejadian ISPA, Status Gizi, Status Imunisasi, Balita

\section{PENDAHULUAN}

Perkembangan penyakit pada bayi di dunia tahun 2016 dapat dilihat dari beberapa data penyakit seperti infeksi saluran pernapasan akut (ISPA) 25\%, diare $7 \%$, asma 5\%, bronkiolitis 5\% dan pneumonia $4,5 \%$. Dari data tersebut ISPA merupakan penyakit yang menyebabkan kematian dan kesakitan tertinggi pada anak yaitu sebanyak 4,25 juta setiap tahunnya (UNICEF, 2016 \& WHO, 2016).

Prevalensi ISPA di Indonesia sendiri prevalensi Infeksi saluran pernapasan akut (ISPA) pada Tahun 2018 adalah 10,0\%. Insidensi ISPA di Sumatera Barat menunjukkan angka berfluktuasi setiap tahun adalah 9,3\%, sedangkan di Sumatera
Barat sendiri prevalensi Infeksi Saluran Pernapasan Akut (ISPA) pada Tahun 2018 adalah 10,0\%. Insidensi ISPA di Sumatera Barat menunjukkan angka berfluktuasi setiap tahun (Riskesdas, 2018)

Angka kematian bayi, Balita dan anak merupakan salah satu indikator kesehatan yang sangat mendasar. Berdasarkan hasil Survei Kesehatan Rumah Tangga (SKRT) tahun 2007, menunjukkan bahwa proporsi kematian bayi akibat ISPA di Indonesia adalah sebesar $30,8 \%$, artinya dari 100 bayi meninggal, 30 diantaranya meninggal karena ISPA. ISPA masih merupakan penyebab kematian terbanyak pada Balita, yakni sebesar 22,8 
$\%$ atau sebesar 4,6 kematian per 1000 Balita.

Secara umum terdapat tiga faktor resiko terjadinya ISPA yaitu faktor lingkungan, faktor individu dan faktor perilaku. Faktor individu yang dapat meningkatkan resiko terjadinya ISPA yaitu umur, BBLR (Bayi Baru Lahir Rendah), status gizi dan status imunisasi. Balita dengan gizi yang kurang akan lebih mudah terserang ISPA dibandingkan Balita dengan gizi normal karena faktor daya tahan tubuh yang kurang. Balita dengan gizi kurang jika terserang penyakit infeksi maka proses penyembuhannya akan lama dibandingkan dengan Balita yang mempunyai gizi baik. Selain itu status imunisasi juga dapat menyebabkan Balita terserang ISPA, Balita yang tidak mendapatkan imunisasi lengkap akan beresiko terserang ISPA dan jika Balita tersebut terserang ISPA maka perkembangan penyakitnya akan menjadi lebih berat karena tidak adanya daya tahan tubuh Balita. Sedangkan Balita yang mendapatkan imunisasi lengkap jika terserang ISPA maka perkembangan penyakitnya tidak akan menjadi lebih berat, selain itu penyakit ISPA juga dapat menyebabkan terjadinya pneumonia jika tidak ditangani dengan cepat (Maryuani, 2010).

Penelitian yang dilakukan oleh (Heryanto, 2016) tentang Hubungan Status Imunisasi, Status Gizi, dan ASI eksklusif dengan Kejadian ISPA pada Anak Balita di Balai Pengobatan UPTD Puskesmas Sekar

\section{METODE PENELITIAN}

Penelitian ini bersifat analitik
kuantitatif dengan pendekatan cross
sectional. Populasi dalam penelitian ini
adalah semua ibu yang mempunyai anak
Balita yang berkunjung ke Puskesmas
Lubuk Buaya Padang pada bulan Februari-
April 2019 yang berjumlah 627 Balita.
Teknik pengambilan sampel yang
digunakan dalam penelitian ini accidental
sampling sebanyak 86 orang. Pengumpulan
data berupa data primer dengan
menggunakan lembar observasi. Data
status gizi didapatkan dengan melihat
catatan, dan penimbangan secara langsung

Jaya Kabupaten Ogan KomEring Ulu, didapatkan hasil $60,7 \%$ Balita menderita ISPA dengan status imunisasi yang tidak lengkap. Hasil uji statistik diperoleh nilai $p$ 0,0001 , hal ini menunjukkan bahwa ada hubungan yang bermakna antara status imunisasi dengan kejadian ISPA. Dan Balita dengan status gizi tidak baik yang menderita ISPA sebanyak $88,9 \%$, dengan hasil uji statistik diperoleh nilai $p \quad 0,000$. Hal ini berarti bahwa ada hubungan yang bermakna antara status gizi dengan kejadian ISPA.

Penelitian yang dilakukan oleh (Yuliastuti, 2014) tentang Hubungan Status Gizi dan Status Imunisasi dengan Kejadian ISPA pada Balita di Puskesmas Cempaka Banjarbaru, didapatkan hasil sebanyak 61 Balita $(58,7 \%)$ yang mengalami ISPA memiliki status gizi buruk. Hasil uji Chi-Square didapatkan nilai $p=0,000<(0,05)$ yang berarti ada hubungan yang bermakna antara status gizi dengan kejadian ISPA pada Balita. Dan sebanyak 120 Balita $(76,9 \%)$ yang mengalami ISPA dengan status imunisasi tidak lengkap. Hasil uji Chi-Square didapatkan nilai $p=0,000<$ $(0,05)$ ini berarti ada hubungan yang bermakna antara status imunisasi dengan kejadian ISPA pada Balita.

Tujuan penelitian ini adalah untuk Hubungan Status Gizi Dan Status Imunisasi Dengan Kejadian Infeksi Saluran Pernapasan Akut (ISPA) Pada Balita Di Puskesmas Lubuk Buaya Kota Padang.

oleh peneliti dengan menggunakan timbangan yang disiapkan oleh peneliti, untuk status imunisasi didapatkan dengan melihat buku KMS, sedangkan untuk kejadian ISPA didapatkan dengan melihat rekam medik dari hasil pemeriksaan klinis oleh tenaga kesehatan. Analisis univariat dilakukan untuk mengetahui distribusi frekuensi (frekuensi setiap variabel diubah dalam satuan persen (\%)). Analisis bivariat dilakukan untuk mengetahui hubungan antara variabel bebas dengan variabel terikat menggunakan uji statistik Chi Square. 


\section{HASIL PENELITIAN}

Tabel 1 Distribusi Frekuensi Karakteristik Responden Berdasarkan Pendidikan dan Pekerjaan

\begin{tabular}{ccccc}
\hline No & $\begin{array}{c}\text { Karakteristik } \\
\text { Responden }\end{array}$ & & F & \% \\
\hline 1 & Pendidikan & SMP & 17 & 19,8 \\
& & SMA & 57 & 66,3 \\
& DIII & 7 & 8,1 \\
& S1 & 5 & 5,8 \\
& \multirow{3}{*}{ Pekerjaan } & Total & $\mathbf{8 6}$ & $\mathbf{1 0 0}$ \\
& & PNS & 3 & 3,5 \\
& & Swasta & 15 & 17,4 \\
& & IRT & 68 & 79,1 \\
\hline & Total & $\mathbf{8 6}$ & $\mathbf{1 0 0}$ \\
\hline
\end{tabular}

Distribusi frekuensi responden berdasarkan pendidikan didapatkan $66,3 \%$ pendidikan ibu SMA, berdasarkan pekerjaan didapatkan $79,1 \%$ pekerjaan ibu adalah IRT (Ibu Rumah Tangga).

Tabel 2 Distribusi Frekuensi Karakteristik Responden Berdasarkan Kejadian Infeksi Saluran Pernapasan Akut (ISPA) Pada Balita

\begin{tabular}{ccc}
\hline Kejadian ISPA & $\boldsymbol{f}$ & $\%$ \\
\hline ISPA & 50 & 58,1 \\
Tidak ISPA & 36 & 41,9 \\
\hline Total & $\mathbf{8 6}$ & $\mathbf{1 0 0}$ \\
\hline
\end{tabular}

Berdasarkan Tabel 2 dapat dilihat bahwa lebih dari separuh (58,1\%) Balita mengalami ISPA di Puskesmas Lubuk Buaya Padang.

Tabel 3 Distribusi Frekuensi Responden Berdasarkan Status Gizi Balita Di Puskesmas Lubuk Buaya Padang

\begin{tabular}{ccc}
\hline Status Gizi & $\boldsymbol{f}$ & \% \\
\hline Gizi Baik & 17 & 19,8 \\
Gizi Sedang & 28 & 32,6 \\
Gizi Kurang & 41 & 47,7 \\
\hline Total & $\mathbf{8 6}$ & $\mathbf{1 0 0}$ \\
\hline
\end{tabular}

Berdasarkan tabel 3 dapat dilihat bahwa kurang dari separuh $(47,7 \%)$ Balita dengan status gizi kurang di Puskesmas Lubuk Buaya Padang.

Tabel 4 Distribusi Frekuensi Responden Berdasarkan Status Imunisasi Balita Di Puskesmas Lubuk Buaya Padang

\begin{tabular}{ccc}
\hline Imunisasi & $\boldsymbol{f}$ & $\%$ \\
\hline Tidak Lengkap & 55 & 64 \\
Lengkap & 31 & 36 \\
\hline Total & $\mathbf{8 6}$ & $\mathbf{1 0 0}$ \\
\hline
\end{tabular}


Berdasarkan tabel 4 dapat dilihat bahwa lebih dari separuh (64\%) Balita dengan imunisasi tidak lengkap di Puskesmas Lubuk Buaya Padang.

Tabel 5 Analisis Bivariat Hubungan Status Gizi dengan Kejadian Infeksi Saluran Pernapasan Akut (ISPA) pada Balita di Puskesmas Lubuk Buaya Padang

\begin{tabular}{|c|c|c|c|c|c|c|c|}
\hline \multirow{3}{*}{$\begin{array}{c}\text { Hubungan antar } \\
\text { Variabel }\end{array}$} & \multicolumn{7}{|c|}{ Kejadian ISPA } \\
\hline & \multicolumn{2}{|c|}{ ISPA } & \multicolumn{2}{|c|}{ Tidak ISPA } & \multicolumn{2}{|c|}{ Total } & \multirow{2}{*}{$p$-value } \\
\hline & $f$ & $\%$ & $f$ & $\%$ & $f$ & $\%$ & \\
\hline \multicolumn{8}{|l|}{ Status Gizi } \\
\hline Gizi Kurang & 37 & $90,2 \%$ & 4 & $9,8 \%$ & 41 & $100 \%$ & \multirow{4}{*}{0,000} \\
\hline Gizi Sedang & 10 & $35,7 \%$ & 18 & $64,3 \%$ & 28 & $100 \%$ & \\
\hline Gizi Baik & 3 & $17,6 \%$ & 14 & $82,4 \%$ & 17 & $100 \%$ & \\
\hline Total & 50 & 58,1 & 36 & 41,9 & 86 & 100 & \\
\hline
\end{tabular}

Tabel 5 menunjukkan bahwa proporsi kejadian sebagian besar terjadi pada status gizi kurang sebanyak 37 Balita $(90,2 \%)$ disbanding gizi baik 3 Balita $(17,6 \%)$ dan gizi sedang 10 Balita $(35,7 \%)$. Hasil analisis statistik dengan uji chisquare diperoleh nilai $p$-value $=0.000(p<)$ berarti ada hubungan yang bermakna antara status gizi dengan kejadian infeksi saluran pernapasan akut (ISPA) pada Balita di Puskesmas Lubuk Buaya Padang.

Tabel 6 Hubungan Status Imunisasi dengan Kejadian Infeksi Saluran Pernapasan Akut (ISPA) pada Balita di Puskesmas Lubuk Buaya Padang

\begin{tabular}{|c|c|c|c|c|c|c|c|}
\hline \multirow{3}{*}{$\begin{array}{c}\text { Hubungan antar } \\
\text { Variabel }\end{array}$} & \multicolumn{7}{|c|}{ Kejadian ISPA } \\
\hline & \multicolumn{2}{|c|}{ ISPA } & \multicolumn{2}{|c|}{ Tidak ISPA } & \multicolumn{2}{|c|}{ Total } & \multirow[t]{2}{*}{ pvalue } \\
\hline & $f$ & $\%$ & $f$ & $\%$ & $f$ & $\%$ & \\
\hline \multicolumn{8}{|l|}{ Status Imunisasi } \\
\hline Tidak Lengkap & 43 & $78,2 \%$ & 12 & $21,8 \%$ & 55 & $100 \%$ & \multirow{3}{*}{0,000} \\
\hline Lengkap & 7 & $22,8 \%$ & 24 & $77,4 \%$ & 31 & $100 \%$ & \\
\hline Total & 50 & $58,1 \%$ & 36 & $41,9 \%$ & 86 & $100 \%$ & \\
\hline
\end{tabular}

Tabel 6 menunjukkan bahwa proporsi kejadian ISPA sebagian besar terjadi pada Balita yang mendapatkan imunisasi tidak lengkap 43 Balita $(78,2 \%)$ dibandingkan dengan Balita yang mendapatkan imunisasi lengkap 7 Balita (22,6\%). Berdasarkan hasil analisis statistik dengan uji chisquare diperoleh nilai $p$ value $=0.000(p<)$ berarti ada hubungan yang bermakna antara status imunisasi dengan kejadian infeksi saluran pernapasan akut (ISPA) pada Balita di Puskesmas Lubuk Buaya Padang.

\section{PEMBAHASAN}

\section{Kejadian ISPA}

Hasil penelitian menunjukkan Balita yang mengalami kejadian ISPA sebanyak $58,1 \%$ Balita. Hasil penelitian ini sejalan dengan penelitian yang dilakukan (Yuliastuti, 2014) tentang "Hubungan Status Gizi dan Status Imunisasi dengan Kejadian ISPA pada Balita di Puskesmas Cempaka Banjarbaru" diketahui dari 1011 Balita didapatkan 509 (50,3\%) Balita mengalami ISPA dan 502 (49,7\%) Balita tidak mengalami ISPA.
Infeksi Saluran Pernapasan Akut (ISPA) adalah suatu kelompok penyakit yang menyerang saluran pernapasan. Penyebab ISPA terdiri dari bakteri,Virus dan jamur. Bakteri penyebab ISPA misalnya Diploccus pneumoniae, Pneumococcus, Streptococcus pyogenes, Staphylococcus aureus, Haemophilus influenza ( $\mathrm{dr} \mathrm{MPH}$, 2011)

Kejadian ISPA yang tergolong tinggi $58,1 \%$ Balita yang mengalami kejadian ISPA, hal ini bisa disebabkan oleh faktorfaktor yang dapat memicu terjadinya ISPA 
seperti imunisasi tidak lengkap dan status gizi kurang. Selain tinggginya angka kejadian ISPA penyakit lainyang banyak dideritaBalitayaitu demam.

\section{Status Gizi}

Hasil penelitian menunjukkan bahwa 47,7\% Balita dengan status gizi kurang dibandingkan 32,6\% Balita dengan status gizi sedang dan 19,8\% Balita dengan status gizi baik di Puskesmas Lubuk Buaya Padang Tahun 2019. Penelitian ini sejalan dengan penelitian (Hariani, Nurbaeti, 2014) didapatkan dari 54 anak 61,1\% dengan status gizi kurang dibandingkan 38,9\% dengan status gizi baik.

Gizi adalah suatu proses organisme menggunakan makanan yang dikonsumsi serta normal melalui proses digesti, absorbsi, transportasi, penyimpanan, metabolism dan pengeluaran zat-zat yang tidak digunakan untuk mempertahankan kehidupan, pertumbuhan dan fungsi normal dari organ-organ serta menghasilkan energi. Berat badan adalah satu parameter yang memberikan gambaran massa tubuh. Massa tubuh sangat sensitif terhadap perubahan-perubahan yang mendadak, misalnya karena terserang penyakit infeksi, penurunan nafsu makan, atau jumlah makanan yang dikonsumsi (Supariasa, 2016).

Balita yang memiliki gizi kurang akan mudah untuk terserang penyakit dibandingkan Balita yang memiliki status gizi baik. Status gizi Balita dapat dikategorikan dalam tiga bagian yaitu gizi baik, gizi sedang dan gizi kurang. Dikatakan gizi baik jika hasil BB/U Balita didapatkan > $80 \%$, dikatakan gizi kurang jika hasil BB/U Balita 71\%-80\% dan dikatakan gizi kurang jika hasil BB/U Balita 61\%-70\%. Jika asupan nutrisi pada Balita terpenuhi maka terjadi perkembangan berat badan pada Balita,sebaliknya jika asupan nutrisi Balita tidak terpenuhi maka perkembangan berat badan pada Balita akan lambat sehingga Balita akan mudah terserang penyakit.

\section{Status Imunisasi}

Hasil penelitian menunjukkan $64 \%$ Balita dengan imunisasi tidak lengkap dibandingkan 36\% Balita dengan imunisasi lengkap di Puskesmas Lubuk Buaya
Padang Tahun 2019. Penelitian ini sejalan dengan penelitian (Hariani, Nurbaeti, 2014) didapatkan dari 54 anak 55,6\% mendapatkan imunisasi tidak lengkap dibandingkan 44,4\% anak mendapatkan imunisasi lengkap.

Imunisasi merupakan pemberian kekebalan tubuh terhadap suatu penyakit dengan memasukkan sesuatu ke dalam tubuh agar tubuh tahan terhadap penyakit yang sedang mewabah atau berbahaya bagi seseorang. Imunisasi terhadap suatu penyakit hanya akan memberikan kekebalan atau resistensi pada penyakit itu saja, sehingga untuk terhindar dari penyakit lain diperlukan imunisasi lainnya. Tujuan diberikan imunisasi adalah harapan anak menjadi kebal terhadap penyakit sehingga dapat menurunkan angka morbiditas dan mortalitas serta dapat mengurangi kecacatan akibat penyakit tertentu.

Imunisasi merupakan peranan penting dalam menciptakan daya tahan tubuh Balita. Balita yang memiliki status imunisasi tidak lengkap seperti masih banyaknya Balita yang tidak mendapatkan imunisasi campak dikarenakan ibu Balita yang berpikir jika diimunisasi anaknya akan mengalami campak dan demam setelah diimunisasi sehingga ibu tidak membawa anaknya ke Posyandu. Hal ini juga disebabkan karena tingkat pengetahuan ibu yang masih kurang mengenai ISPA, didukung dengan pendidikan ibu yang mayoritasnya SMA 66,3\%.

\section{Hubungan Status Gizi dengan Kejadian Infeksi Saluran Pernapasan Akut (ISPA)}

Berdasarkan hasil penelitian menunjukkan bahwa proporsi kejadian ISPA sebagian besar ditemukan pada Balita dengan status gizi kurang 90,2\% dibandingkan Balita dengan status gizi baik $17,6 \%$ dan Balita dengan status gizi sedang $35,7 \%$. Hasil uji statistik dengan uji Chi-Square menunjukkan p-value $0,000<$ 0,05 berarti terdapat hubungan yang bermakna antara status gizi dengan kejadian ISPA pada Balita di Puskesmas Lubuk Buaya Padang Tahun 2019.

Hubungan status gizi dengan kejadian ISPA dapat dilihat dari hasil pengukuran $\mathrm{BB} / \mathrm{U}$ sebagian besar $(90,2 \%)$ 
status gizi kurang, dapat diakibatkan oleh kurangnya nafsu makan Balita sehingga sistem daya tahan tubuh Balita menurun dan Balita akan mudah terserang penyakit.

Penelitian ini sejalan dengan penelitian yang dilakukan oleh (Heryanto, 2016) tentang "Hubungan Status Imunisasi dan Status Gizi dan ASI Esklusif dengan Kejadian ISPA pada Anak Balita di Balai Pengobatan UPTD Puskesmas Sekar Jaya Kabupaten Ogan KomEring Ulu" menggunakan uji Chi-Square dengan tingkat signifikasi pvalue 0,05 diperoleh hasil $p=0,000(p<)$. Dari hasil penelitian tersebut membuktikan bahwa status gizi memiliki hubungan yang bermakna dengan kejadian ISPA pada Balita di Balai Pengobatan UPTD Puskesmas Sekar Jaya Kabupaten Ogan Kom Ering Ulu.

Status gizi yang baik terjadi bila tubuh memperoleh asupangizi yang cukup sehingga dapat digunakan oleh tubuh untuk pertumbuhan fisik, perkembangan otak dan kecerdasan serta daya tahan tubuh terhadap infeksi secara optimal (Marimbi Hanum, 2010).

Keadaan gizi yang buruk muncul sebagai faktor resiko yang penting untuk terjadinya ISPA. Beberapa penelitian telah membuktikan tentang adanya hubungan antara status gizi buruk dan infeksi paru, sehingga anak-anak bergizi buruk sering mendapatkan pneumonia. Disamping itu adanya hubungan status gizi buruk dan terjadinya campak dan infeksi virus berat lainnya serta menurunnya daya tahan tubuh anak terhadap infeksi (Maryuani, 2010)

Balita dengan gizi yang kurang akan lebih mudah terserang ISPA dibandingkan dengan Balita dengan gizi normal, karena faktor daya tahan tubuh yang kurang. Penyakit infeksi sendiri akan menyebabkan Balita tidak mempunyai nafsu makan dan mengakibatkan kekurangan gizi. Pada keadaan gizi kurang, Balita lebih mudah terserang ISPA dan serangannya akan lebih lama (Maryuani, 2010).

Hubungan status gizi dengan kejadian ISPA pada Balita sebagian besar terjadi pada Balita yang mempunyai status gizi kurang yang didapatkan dari hasil pengukuran BB/U sebanyak 90,2\% lebih banyak dibandingkan Balita yang gizi baik $17,6 \%$ dan gizi sedang $35,7 \%$ yang menderita penyakitl SPA. Hal ini disebabkan karena ibu kurang memperhatikan asupan nutrisi pada Balita. Asupan gizi yang diberikan pada Balita bukan untuk memberikan kekebalan tubuh terhadap ISPA secara langsung, melainkan untuk mencegah faktor-faktor yang dapat memicu terjadinya ISPA pada Balita.

Dari penelitian juga ditemukan Balita yang berstatus gizi baik dan sedang tapi terkena ISPA,hal ini bisa disebabkan oleh faktor lain seperti imunisasi Balita yang tidak lengkap sebanyak 64\%. Dan Balita yang status gizinya baik dan sedang dan tidak ISPA hal ini disebabkan oleh lengkapnya imunisasi sebanyak 36\%.

\section{Hubungan Status Imunisasi dengan Kejadian Infeki Saluran Pernapasan Akut(ISPA)}

Hasil penelitian menunjukkan kejadian penyakit ISPA sebagian besar ditemukan pada Balita dengan status imunisasi tidak lengkap yaitu sebanyak $78,2 \%$ dibandingkan Balita dengan status imunisasi lengkap yaitu sebanyak 22,6\%. Hasil uji statistik dengan uji Chi-Square menunjukkan $p$ value $0,000<0,05$ berarti terdapat hubungan yang bermakna antara status imunisasi dengan kejadian ISPA pada Balita di Puskesmas Lubuk Buaya Padang Tahun 2019.

Penelitian ini sejalan dengan penelitian yang dilakukan oleh (Yuliastuti, 2014) tentang "Hubungan Status Gizi dan Status Imunisasi dengan Kejadian ISPA pada Balita di Puskesmas Cempaka Banjar baru" menggunakan uji Chi-Square dengan tingkat signifikasi $p$-value 0,05 diperoleh hasil $p=0,000$ ( $p<0,000$ ). Dari hasil penelitian tersebut membuktikan bahwa ada hubungan yang bermakna antara status imunisasi dengan kejadian ISPA pada Balita di Puskesmas Cempaka Banjar baru.

Hal ini disebabkan karena Balita dengan status imunisasi lengkap memiliki sistem kekebalan tubuh yang baik untuk mencegah terjadinya penyakit atau penularan penyakit seperti ISPA, sebaliknya Balita dengan status imunisasi tidak lengkap akan cenderung memiliki sistem kekebalan tubuh yang lemah sehingga memudahkan untuk terjadinya penyakit seperti ISPA. Sebagian besar kematian ISPA berasal dari jenis ISPA yang berkembang dari penyakit yang dapat dicegah dengan imunisasi 
seperti difteri, pertusis, dan campak, maka cakupan peningkatan imunisasi akan berperan besar dalam upaya pemberantasan ISPA. Untuk mengurangi faktor yang meningkatkan mortalitas ISPA, diupayakan imunisasi lengkap (Yuliastuti, 2014).

Status imunisasidari hasil observasi dapat dilihat bahwa kelengkapan imunisasi Balita dengan status imunisasi tidak lengkap $78,2 \%$ cenderung akan mengalami penyakit ISPA, lebih banyak dibandingkan Balita yang status imunisasi lengkap 22,6\% yang mengalami penyakit ISPA. Hal ini disebabkan oleh masih banyaknya ibu Balita yang tidak membawa anaknya ke Posyandu untuk diimunisasi karena takut anaknya akan demam setelah diimunisasi, dan ada juga ibu Balita yang mau membawa anaknya untuk diimunisasi tetapi setiap kali mau dibawa imunisasi anaknya demam sehingga ibu tidak mau lagi membawa anaknya imunisasi.

Dari hasil penelitian juga ditemukan ibu yang mempunyai Balita dengan status

\section{DAFTAR PUSTAKA}

dr MPH, W. (2011). Penyakit Tropis Epidemiologi, Penularan, Pencegahan Dan Pemberantasannya. In Penyakit Tropis Epidemiologi, Penularan, Pencegahan Dan Pemberantasannya.

Hariani, Nurbaeti, N. (2014). Hubungan status imunisasi, status gizi, dan asap rokok dengan kejadian ispa pada anak dipuskesmas segeri pangkep. Jurnal IImu Kesehatan Diagnosis, 5(5), 639643.

Heryanto, E. (2016). Hubungan Status Imunisasi, Status Gizi, dan ASI Eksklusif dengan kejadian ISPA pada Anak Balita di Balai Pengobatan UPTD Puskesmas Sekar Jaya Kabupaten Ogan Kom Ering Ulu. Kesehatan imunisasi lengkap dan terkena ISPA, hal ini bisa disebabkan karena asupan gizi yang kurang dan kurangnya pengetahuan ibu tentang ISPA. Juga terdapat ibu yang mempunyai Balita dengan status imunisasi tidak lengkap dan tidak terkena ISPA hal ini dikarenakan asupan gizi yang baik sehingga dapat mencegah faktor-faktor yang dapat memicu terjadinya ISPA pada Balita.

\section{KESIMPULAN DAN SARAN}

Status gizi dan status imunisasi merupakan faktor yang mempengaruhi kejadian infeksi saluran pernafasan akut pada Balita. Balita dengan keadaan gizi yang kurang akan lebih mudah terserang ISPA dibandingkan Balita dengan status gizi normal, Balita yang tidak mendapatkan imunisasi lengkap akan beresiko terserang ISPA. Meningkatkan asupan nutrisi pada Balita yang gizi kurang dan diharapkan kepada petugas Puskesmas agar memberikan penyuluhan kepada ibu tentang pentingnya imunisasi.

Masyarakat.

Maryuani, A. (2010). Ilmu Kesehatan Anak Dalam Kebidanan. IImu Kesehatan Anak Dalam Kebidanan. Jakarta: Trans Info Media.

Riskesdas. (2018). Riset Kesehatan Dasar 2018. Kementrian Kesehatan Republik Indonesia. https://doi.org/1 Desember 2013

Supariasa, I. D. N. (2016). Perencanaan Gizi. In IImu Gizi Teori \& Aplikasi. https://doi.org/10.1037/00332909.128.6.978

Yuliastuti, E. (2014). Hubungan status gizi dan status imunisasi dengan kejadian ISPA pada Balita. Jurnal Dinamika Kesehatan. 